\title{
THE MUTUAL RELATIONSHIP BETWEEN REGIONAL INCOME AND DEFORESTATION: A STUDY ON TURKEY
} (1)

\author{
Zeynep ELBURZ* ${ }^{*}$ K. Mert ÇUBUKÇU* and Peter NIJKAMP*****
}

Received: 05.01.2017; Final Text: 18.01.2018

Keywords: Economic growth; simultaneousequations; deforestation; two-stage regression.

1. Bu çalışma 10-12 Mayıs 2018 tarihinde Marmara Üniversitesi ev sahipliğinde düzenlenen 18. Ulusal Bölge Bilimi ve Bölge Planlama Kongresi'nde sunulmuştur.

\footnotetext{
* Department of City and Regional Planning, Faculty of Architecture, Dokuz Eylul University, İzmir, TURKEY.

** Adam Mickiewicz University, Poznan, POLAND.

*** JADS, 's-Hertogenbosch, THE NETHERLANDS.
}

\section{INTRODUCTION}

As a significant determining supply factor for economic growth, the quantity and the quality of natural resources have been widely investigated in the economic literature. The magnitude of environmental degradation due to economic growth has also been explored and assessed to an admirable extent. This paper aims to show how economic growth causes environmental deterioration, while the environmental resources function in turn as a supply factor. This mutual two-way relationship of economic growth and environmental degradation is analyzed using a simultaneousequations model, where economic growth is measured by regional income, and environmental deterioration by deforestation.

Since the 1980's, deforestation has been seen as a major global environmental problem due to its effect on climate change and biodiversity (Barbier, 2001). Deforestation, an indisputable measure of deterioration of the environment, covers a wide range of meanings (Choumert et al. 2013). According to The Food and Agriculture Organization of the United Nation (FAO, 2001), deforestation is "the conversion of forest to other land use or the long-term reduction of the tree canopy cover below the minimum 10 percent threshold". The Marrakech Accords to the Kyoto Protocol under United Nations Framework Convention on Climate Change (UNFCCC, 2001) describes deforestation concisely as "the direct human-induced conversion of forested land to non-forested land" with an emphasis on the human-effect. Despite the global concern on forest area loss, which is about 129 million hectares from 1990 to 2015 (FAO, 2015), the number and scope of the quantitative studies focusing on the drivers and outcomes of deforestation has remained limited (FAO, 2016). In this study, based on UNFCCC's description, deforestation is defined as the annual change from a forest to a non-forest state to analyze the mutual relationship between regional income and deforestation in Turkey, which possess 22.3 million hectares of forest, nearly 30\% of its total land area by the year 2015 (The 
Ministry of Forestry and Water Affairs, 2015). Taking into account that Turkish economy has grown approximately $3.4 \%$ annually, while it has lost approximately 50,000 hectares forest land per year between the years 2004 and 2014, it is essential to examine this mutual link in an emerging economy.

The remaining part of the paper is organized as follows. Section 2 consists of a literature review of deforestation and economic growth concepts. Then section 3 introduces an overview of the methodology and data, while Section 4 presents the results of the analyses. Finally, Section 5 concludes the research with a discussion and suggestions for policy makers.

\section{LITERATURE REVIEW}

The Environmental Kuznets Curve (EKC) hypothesis has been the prevailing approach in studies on the relationship between income and deforestation (Scrieciu, 2007). The EKC hypothesis suggests that this relationship follows an inverted U-shaped form. That is to say, environmental degradation is inevitable during the first stage of the development, but environmental restoration begins as income continues to increase (Bhattarai and Hamming, 2001). This approach has captured a significant amount of attention after the 1990's, mostly due to the availability of global pollutant data from the Global Environmental Monitoring System (Dinda, 2004). Following Panayotou's (1993) pioneering paper, many researchers have tested the relations of EKC for deforestation (Table 1).

The results of studies on EKC hypothesis for deforestation are controversial. Bhattarai and Hamming (2001) find a significant evidence of the validity the EKC hypothesis in African, Asian and Latin American countries. Cropper and Griffiths (1994) employ data from 1961 to 1991 from 64 countries, and conclude in favor of the EKC hypothesis. Further, Basu and Nayak (2011) and Zhang et al. (2006) reach similar results for India and China. Whereas, Koop and Tole (2001) report contradictory findings using data from 48 developing countries for the years between 1961 and 1992. Considering the variety and diversity of the country characteristics, they state that the results are not surprising (Barbier, 2001; Koop and Tole, 1999).

Table 1. EKC studies for deforestation. To have a better understanding on the EKC for deforestation, Choumert et

\begin{tabular}{lllll}
\hline Year & Author(S) & Geographic coverage & Time period & Findings \\
1994 & Cropper and Griffiths & 64 countries & $1961-1991$ & EKC exists in Latin America and Africa \\
2001 & Bhattarai and Hamming & 66 countries & $1972-1991$ & EKC exists in Latin America and Africa \\
2001 & Koop and Tole & 48 countries & $1961-1992$ & Depends on income level \\
2001 & Barbier & Tropical countries & $1961-1994$ & Depends on regions \\
2002 & Ehrhardt-Martinez et al. & 74 countries & $1980-1995$ & EKC exists \\
2003 & Foster and Rosenzweig & 250 Indian villages & $1971-1999$ & EKC exists in closed economies \\
2003 & Meyer et al. & 117 countries & $1990-2000$ & EKC does not exist \\
2004 & Barbier & Latin American countries & $1961-1994$ & Depends on model specification \\
2006 & Zhang et al. & China & $1990-2001$ & EKC exists \\
2007 & Culas & 14 tropical countries & $1972-1994$ & EKC exists in Latin America \\
2011 & Basu and Nayak & India & $1994-2006$ & EKC exists \\
\hline
\end{tabular}


al. (2013) analyze 547 estimations from 69 studies, published between 1992 and 2012, using meta-analysis, and conclude that the findings of recent studies are not in line with the EKC hypothesis. It is noteworthy to state that Stern et al. (1996) and Stern (2004) underline the econometric problems of the EKC studies, which are based on an assumption of uni-directional causality from growth to environmental quality. Single-equation estimations with OLS generate biased and inconsistent results (Stern et al, 1996,) when the fact that the economy and its environment are jointly determined is ignored (Perrings, 2002).

Although the factors affecting deforestation vary by place and difficult to generalize (Murali and Hedge, 1997), Angelsen and Kaimowitz (1999) introduce an approach to investigate the determinants of deforestation based on main sources, immediate causes, and underlying causes by reviewing 140 papers on economic models on deforestation. According to Angelsen and Kaimowitz (1999) and Geist and Lambin (2001), the main sources of deforestation are the agents' actions such as agricultural expansion, wood extraction and infrastructure extensions. However, these main causes are often influenced by macroeconomic and demographic factors, such as income growth, population growth and population density, and these factors are considered as the underlying causes of deforestation (Angelsen and Kaimowitz, 1999).

The findings of the studies on underlying causes of deforestation are also inconclusive and heterogeneous. For the case of income growth, Kant and Redantz (1997) find a positive relationship between income growth and deforestation in their maximum-likelihood estimation model using data from 35 African, 13 Asian, and 17 Latin-American countries. However, Damette and Delacote (2012) analyze 59 developing countries using a quantile regression model with a 23-year panel dataset, and conclude that growth is negatively related to deforestation.

Empirical results from multi-country regressions suggest that deforestation and population are positively correlated. Bhattarai and Hamming (2001) examine 66 countries between the years 1972 and 1991 with variables on population growth and rural population density. According to the fixed effects models results, estimated by weighted least square, population growth coefficient is negative and significant for Latin American and African countries, while it is positive and significant for Asian countries. In the case of rural population density, the results are vice-verse. It is concluded that even though the impact of deforestation varies over countries, the population structure is the key determinant. Deacon (1994) uses ordinary least squares (OLS) regression to estimate the sources of deforestation using a cross section data from 120 countries, and concludes that population growth has a significant effect on deforestation. Finally, Cropper and Griffiths (1994) state that the rural population density has a significant and positive effect on deforestation only in African countries, while in Latin-American and Asian countries this effect is insignificant.

Clearly, the previous studies are of little help for understanding the mutual characteristics of the relationship between economic growth and deforestation. The aim of this research is to provide new insights into this relationship by introducing a simultaneous equations model to test this two-way relationship empirically in an emerging economy. Lastly, we use an up-to-date deforestation data available from the University of Maryland to characterize forest extent, instead of consistent and well-known, but reported to be unsatisfactory and insufficient data from FAO (Scrieciu, 
2007; Angelsen and Kaimowitz, 1999; Lopez and Galinato, 2005; Barbier, 2001). To an authors' knowledge, this is a very first attempt to test this mutual relationship empirically with a new and more reliable deforestation data.

\section{DATA AND METHODOLOGY}

Following Angelsen and Kaimowitz (1999)'s well-accepted approach, we investigate the underlying (indirect) causes of deforestation along with regional economic development with a simultaneous equations model. We use data from 26 NUTS 2 regions in Turkey between the years 2004 and 2014. Descriptions of the variables used in the analysis and their descriptive statistics are summarized in Table 2 and Table 3.

In our model, economic growth, or an increased standard of living for the clear majority of citizens (Friedman, 2006), is measured with regional Gross Domestic Product (GDP) per capita. In line with the UNFCCC's (2001) definition, deforestation is defined as a change from a forest to a nonforest state. As Kaimowitz and Angelsen (1998) note satellite images can well be used to measure forest cover loss. We use up-to-date deforestation data available from the University of Maryland. The data was initially introduced by Hansen et al. (2013), which provide annually updated highresolution global maps of the 21st century forest cover change. The dataset is freely available, and it is based on the results from time-series analyses of Landsat images at a spatial resolution of 30 meters. This data is processed using a Geographical Information System (GIS) to obtain forest loss at the NUTS 2 level in Turkey. As proposed by Moody (1974), we use industrial electricity consumption per capita as a proxy for private capital stock. We also employ a percentage of university graduates in the total population of the region to represent a human capital variable in the production function which is seen as one of the main contributors of income growth since the inspiring work of Romer (1990). In the light of the critics about employing population as a dependent variable to estimate deforestation, we adopt rural population density with a 1 year lag to reduce the simultaneity issues. Lastly, we employ a growth variable to examine not only the levels of income and population, but also the changes of these variables in the model.

Table 2. Definitions of the variables.

\begin{tabular}{|c|c|c|c|c|}
\hline Variable & Description & Year Coverage & Data Source & Unit \\
\hline $\mathbf{Y}$ & GDP per capita & 2004-2014 & Turkstat & per capita \\
\hline YL & 5-year lagged GDP per capita & $2009-2014$ & Turkstat & per capita \\
\hline D & $\begin{array}{l}\text { Deforestated area }\left(\mathrm{km}^{2}\right) \text { divided by total surface area } \\
\left(\mathrm{km}^{2}\right)\end{array}$ & 2004-2014 & $\begin{array}{l}\text { Hansen et al. } \\
(2013)\end{array}$ & $\mathrm{km}^{2}$ \\
\hline DL & 5-year lagged deforestation & 2009-2014 & $\begin{array}{l}\text { Hansen et al. } \\
\text { (2013) }\end{array}$ & $\mathrm{km}^{2}$ \\
\hline YG & Annual GDP per capita growth & $2005-2014$ & Turkstat & $\%$ \\
\hline PG & Annual rural population growth & $2008-2012$ & Turkstat & $\%$ \\
\hline K & Industrial electricity consumption & 2004-2014 & Turkstat & per capita \\
\hline $\mathbf{L}$ & Employment & $2004-2014$ & Turkstat & number of people \\
\hline H & University graduates divided by total population & 2004-2014 & Turkstat & number of people \\
\hline PD & $\begin{array}{l}\text { 1-year lagged rural population divided by regional } \\
\text { arable land (ha) }\end{array}$ & 2007-2012 & Turkstat & ratio \\
\hline
\end{tabular}




\begin{tabular}{|c|c|c|c|c|c|c|}
\hline & \\
\hline & Variable & $\mathbf{N}$ & Mean & $\begin{array}{l}\text { Standard } \\
\text { Deviation }\end{array}$ & Min & Max \\
\hline & $\mathbf{Y}($ GDP per capita) & 286 & 9.276 & 0.520 & 8.027 & 10.596 \\
\hline & K (private capital) & 286 & -0.370 & 1.074 & -3.503 & 1.512 \\
\hline & L (employment) & 286 & 13.456 & 0.605 & 12.117 & 15.444 \\
\hline & H (human capital) & 286 & -0.776 & 0.707 & -2.656 & 1.782 \\
\hline & D (deforestation) & 286 & -3.797 & 2.018 & -8.132 & -0.127 \\
\hline & YG (GDP growth) & 260 & 0.845 & 1.307 & -2.576 & 3.253 \\
\hline & PD (rural density) & 176 & -0.103 & 0.924 & -3.447 & 2.968 \\
\hline & PG (rural pop. growth) & 170 & -0.776 & 0.707 & -2.656 & 1.782 \\
\hline & YL (lagged GDP) & 156 & 9.000 & 0.436 & 8.027 & 10.007 \\
\hline Table 3. Descriptive statistics for the & DL (lagged deforestation) & 156 & -3.736 & 1.991 & -7.912 & -0.127 \\
\hline
\end{tabular}

Table 3. Descriptive statistics for the variables.
Focusing only on macroeconomic underlying causes and adoption, a twostep procedure with instrumental variables is highly useful, since mixing these levels in a single model can lead to misspecification in the regression (Deininger and Minten 1996; Kant and Redantz 1997). Following Carlino and Mills (1987) we employ a simultaneous equations model to assess the mutual relationship between deforestation and economic growth. In this two-step regression model, there are two dependent variables, deforestation and GDP per capita, which are treated as endogenous, while all other explanatory variables are treated as exogenous to the system.

Firstly, we use an augmented Cobb-Douglas production function to estimate the effect of deforestation, as a proxy for environmental degradation, on regional output along with the other independent variables. As stated in Savage et al. (1974), environment can be viewed as a function of production in an expanded eco-economic production function along with the traditional ones. Following Lopez (1994), we employ the environment as a function of production and we add 5-year lagged deforestation, private capital, labor and human capital as inputs to the model.

The expanded production function model that we use can be expressed as (1):

$$
L n Y_{i}=\alpha+8 \operatorname{Ln} K_{i}+\gamma L n L_{i}+\delta L n H_{i}+\vartheta L n D L_{i}+\varepsilon_{i}
$$

where $Y, K, L, H, D L$, and i denote the GDP per capita, private capital, employment, human capital, lagged deforestation, and time respectively.

The second step of the analysis is the measurement of the causes of deforestation with cross sectional regression. We use 5-year lagged GDP per capita, GDP per capita growth, rural population density, and rural population growth variables to estimate their effects on deforestation at the regional level. The model can be express as (2):

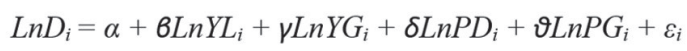

where D, YL, YG, PD, PG, and i indicate deforestation, lagged GDP per capita, GDP per capita growth, rural population density, rural population growth, and time respectively. 
Considering the availability of better and reliable data on deforestation and other explanatory variables, it is a good fit to investigate deforestation at a regional scale instead of using global regression models (Kaimowitz and Angelsen, 1998). However, choosing regional scale for the analysis may cause endogeneity problems, due to the underlying causes of deforestation such as rural population and income level (Reis and Guzman, 1994). Ignoring the endogeneity problem and estimating the models with Ordinary Least Squares (OLS) may lead biased and inconsistent results (Angrist and Imbens, 1995). The endogeneity problem can be solved by two-stage least squares (2SLS) estimation, which is the second in popularity for estimating linear regressions in applied economics (for more information, see Wooldridge, 2015). As Studenmund (2001) states, in the estimation of simultaneous equations systems, two-stage least squares model is more preferable than OLS, because it has less expected bias. Therefore, we estimate the structural equations (1) and (2) using a twostage least squares (2SLS) regression, where we employ lagged variables to overcome the causality problems between the dependent and independent variables.

\section{EMPIRICAL RESULTS}

The results of the 2SLS simultaneous equation estimations for deforestation and GDP per capita are presented in Table 4. According to the first model, lagged deforestation, private capital, employment and human capital variables appear to positively affect GDP per capita with a high level of significance, as expected. In addition to this effect, column 2 displays the same significant and positive but stronger effect of lagged GDP per capita on the deforestation variable. The estimation results are in line with previous studies including Panayotou (1993), Kant and Redantz

\begin{tabular}{|c|c|c|c|}
\hline & & $\begin{array}{l}\text { GDP } \\
(1)\end{array}$ & $\begin{array}{c}\text { Deforestation } \\
\text { (2) }\end{array}$ \\
\hline & Lag_Deforestation & $\begin{array}{c}0.035 * * * \\
(0.012)\end{array}$ & - \\
\hline & Lag_GDP & - & $\begin{array}{c}3.493 * * * \\
(0.283)\end{array}$ \\
\hline & Capital & $\begin{array}{c}0.088 * * * \\
(0.021)\end{array}$ & - \\
\hline & Employment & $\begin{array}{c}0.296 * * * \\
(0.034)\end{array}$ & - \\
\hline & Human Capital & $\begin{array}{c}0.144 * * * \\
(0.025)\end{array}$ & - \\
\hline & GDP Growth & - & $\begin{array}{l}-0.070 \\
(0.336)\end{array}$ \\
\hline & Rural Pop. Growth & - & $\begin{array}{l}-0.018 \\
(0.055)\end{array}$ \\
\hline & Rural Density & - & $\begin{array}{c}1.096 * * * \\
(0.119)\end{array}$ \\
\hline & Constant & $\begin{array}{c}5.490 * * * \\
(0.474)\end{array}$ & $\begin{array}{c}-34.348 * * * \\
(2.342)\end{array}$ \\
\hline & $\mathbf{R}^{2}$ & 0.812 & 0.645 \\
\hline & Time effects & Yes & Yes \\
\hline Table 4. Results of 2SLS estimation. Note: & Observation & 144 & 144 \\
\hline 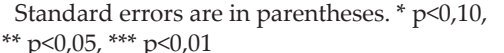 & F-statistic & 64.45 & 27.07 \\
\hline
\end{tabular}

Table 4. Results of 2SLS estimation. Note: Standard errors are in parentheses. ${ }^{*} \mathrm{p}<0,10$, ** $p<0,05,{ }^{* * *} p<0,01$ 
(1997), Bhattarai and Hamming (2001), Barbier (2001), and Damante and Delacote (2012). The results from Model 2 show that not only the lagged GDP per capita, but also the rural density affects deforestation positively. The findings indicate that 1-unit increase in rural population density causes deforestation to grow with 1.096 units, which is consistent with the findings in Basu and Nayak (2011) and Uusivuori et al (2002). Whereas, income growth and rural population growth have no significant effect on deforestation (Table 4).

Economic factors in Model 1 explain $81.2 \%$ of the variation in regional income growth along with the deforestation variable, while in Model 2 , determinants of deforestation explain $64.5 \%$ of the variation in deforestation. These values are plausible, since the variables that added one to the models are not the main sources of deforestation, but rather $y$-the macroeconomic underlying causes of deforestation. Previous studies for example Deacon (1994) and Cropper and Griffiths (1994) have also reached similar $\mathrm{R}^{2}$ values, examining only population and income variables from different countries.

\section{CONCLUSION}

Environmental and economic instability concerns appear to have many complex dimensions. In this paper, we have assessed the mutual relationship between regional income and environmental degradation in Turkish NUTS 2 regions by using a simultaneous equations model. The two-stage least squares estimation results provide prominent evidence on the positive effects of deforestation and regional income for Turkish regions. This statistically significant mutual relationship can also be seen for rural population density; however, it disappears when rural population growth and income growth factors are examined in the same model. The findings of simultaneous-equations models boost the concerns about environmental degradation, since it increases as income increases. Although the initial studies (Beckerman, 1992; Panayotou, 1993) suggest that fostering economic growth is one of the best ways to obtain decent environment at the early stages of the development, it is wrong to rely on only economic growth for environmental problems (Neumayer, 1998). Indeed, environmental and economic goals need to be pursued simultaneously in a mutually-reinforcing way, which is the key strategy to green growth policies (OECD 2010; 2011). In emerging economies, like Turkey, it is crucial to implement the green growth policies to prevent environmental deterioration and promote economic growth at the same time.

This study depicts clearly how regional development affects deforestation and vice versa quantitatively. The next step is to examine this phenomenon in a geographical perspective to assess the effects of location.

\section{REFERENCES}

ANGELSEN, A., KAIMOWITZ, D. (1999) Rethinking the Causes of Deforestation: Lessons from Economic Models, The World Bank Research Observer 14(1) 73-98.

ANGRIST, J. D., IMBENS, G. W. (1995) Two-Stage Least Squares Estimation of Average Causal Effects in Models with Variable Treatment Intensity, Journal of the American statistical Association 90(430) 431-42. 
BARBIER, E. B. (2001) The Economics of Tropical Deforestation and Land Use: An Introduction to the Special Issue, Land Economics 77(2) 15571.

BARBIER, E. B. (2004) Agricultural Expansion, Resource Booms and Growth in Latin America: Implications for Long-Run Economic Development, World Development 32(1) 137-57.

BASU, A., NAYAK, N. C. (2011) Underlying Causes of Forest Cover Change in Odisha, India, Forest Policy and Economics 13(7) 563-9.

BECKERMAN, W. (1992) Economic Growth and the Environment: Whose Growth? Whose Environment?, World Development (20) 481-96.

BHATTARAI, M., HAMMIG, M. (2001) Institutions and the Environmental Kuznets Curve for Deforestation: A Crosscountry Analysis for Latin America, Africa and Asia, World Development 29(6) 995-1010.

CARLINO, G. A., MILLS, E. S. (1987) The Determinants of County Growth, Journal of Regional Science 27(1) 39-54.

CHOUMERT, J., MOTEL, P. C., DAKPO, H. K. (2013) Is the Environmental Kuznets Curve for deforestation a threatened theory? A metaanalysis of the literature, Ecological Economics (90) 19-28.

CROPPER, M., GRIFFITHS, C. (1994) The Interaction of Population Growth and Environmental Quality, The American Economic Review 84(2) 2504 .

CULAS, R. J. (2007) Deforestation and the Environmental Kuznets Curve: An Institutional Perspective, Ecological Economics 61(2) 429-37.

DAMETTE, O., DELACOTE, P. (2012) On the Economic Factors of Deforestation: What Can We Learn from Quantile Analysis?, Economic Modelling 29(6) 2427-34.

DEACON, R. T. (1994) Deforestation and the Rule of Law in a CrossSection of Countries, Land Economics 414-30.

DEININGER, K., MINTEN, B. (1996) Poverty, Policies, and Deforestation: The Case of Mexico, Research Project on Social and Environmental Consequences of Growth-Oriented Policies, Working Paper No. 5. Policy Research Department, World Bank, Washington, DC.

DINDA, S. (2004) Environmental Kuznets Curve Hypothesis: A Survey, Ecological Economics 49(4) 431-55.

EHRHARDT-MARTINEZ, K., CRENSHAW, E. M., JENKINS, J. C. (2002) Deforestation and the Environmental Kuznets Curve: A CrossNational Investigation of Intervening Mechanisms, Social Science Quarterly 83(1) 226-43.

FOOD AND AGRICULTURE ORGANIZATION OF THE UNITED NATIONS. (2001) Global Forest Resources Assessment 2000 Main Report, FAO Forestry Paper 140, Rome.

FOOD AND AGRICULTURE ORGANIZATION OF THE UNITED NATIONS. (2015) Global Forest Resources Assessment 2015, FAO Forestry Paper No.1, UN Food and Agriculture Organization, Rome.

FOOD AND AGRICULTURE ORGANIZATION OF THE UNITED NATIONS. (2016) State of the World's Forests 2016, Forests and Agriculture: Land-Use Challenges and Opportunities, Rome. 
FOSTER, A. D., ROSENZWEIG, M. R. (2003) Economic Growth and the Rise of Forests, The Quarterly Journal of Economics 118(2) 601-37.

FRIEDMAN, B. M. (2006) The Moral Consequences of Economic Growth, Society 43(2) 15-22.

GEIST, H. J., LAMBIN, E. F. (2001) What Drives Tropical Deforestation, LUCC Report series 4 (116).

HANSEN, M. C., POTAPOV, P. V., MOORE, R., HANCHER, M., TURUBANOVA, S. A., TYUKAVINA, A., KOMMAREDDY, A., EGOROV, A., CHINI, L., JUSTICE, C. O., TOWNSHEND, J. R.G. (2013) High-Resolution Global Maps of 21st-Century Forest Cover Change, Science 342(6160) 850-53.

KAIMOWITZ, D., ANGELSEN, A. (1998) Economic Models of Tropical Deforestation: A Review, Centre for International Forestry Research, Jakarta.

KANT, S., REDANTZ, A. (1997) An Econometric Model of Tropical Deforestation, Journal of Forestry Economics (3) 51-86.

KOOP, G., TOLE, L. (1999) Is There an Environmental Kuznets Curve for Deforestation?, Journal of Development Economics 58(1) 231-44.

KOOP, G., TOLE, L. (2001) Deforestation, Distribution and Development, Global Environmental Change 11(3) 193-202.

LOPEZ, R. (1994) The Environment As a Factor of Production: The Effects of Economic Growth and Trade Liberalization, Journal of Environmental Economics and Management 27(2) 163-84.

LÓPEZ, R., GALINATO, G. I. (2005) Trade Policies, Economic Growth, and the Direct Causes of Deforestation, Land Economics 81(2) 145-69.

MEYER, A. L., VAN KOOTEN, G. C., WANG, S. (2003) Institutional, Social and Economic Roots of Deforestation: A Cross-Country Comparison, International Forestry Review 5(1) 29-37.

MOODY, C. E. (1974) The Measurement of Capital Services by Electrical Energy, Oxford Bulletin of Economics and Statistics 36(1) 45-52.

MURALI, K.S., HEDGE, R. (1997) Patterns of Tropical Deforestation, Journal of Tropical Forest Science 9(4) 465-76.

NEUMAYER, E. (1998) Is Economic Growth the Environment's Best Friend?, Zeitschrift fur Umweltpolitik und Umweltrecht (21) 161-76.

ORGANISATION FOR ECONOMIC CO-OPERATION AND DEVELOPMENT. (2010). The Green Growth Strategy. How Can We Get to a Greener Economy?. [http://www.oecd.org/greengrowth/46141709. pdf] Access Date (02.08.2016).

ORGANISATION FOR ECONOMIC CO-OPERATION AND DEVELOPMENT. (2011). Towards Green Growth. [http://dx.doi. org/10.1787/9789264111318-en] Access Date (02.08.2016).

PANAYOTOU, T. (1993) Empirical Tests and Policy Analysis of Environmental Degradation at Different Stages of Economic Development, Working Paper Wp238. Technology and Employment Programme, International Labor Office, Geneva. 
PERRINGS, C. (2002) Resilience and Sustainability, Frontiers of Environmental Economics, eds. H. Folmer, L. Gabel, S. Gerkin, A. Rose, Edward Elgar Publishing, Lincolnshire.

REIS, E., GUZMAN, R. (1994) An Econometric Model of Amazon Deforestation, The Causes of Tropical Deforestation, the Economic and Statistical Analysis of Factors Giving Rise to the Loss of Tropical Forests, eds. K. Brown, D. Pearce University College London Press, London; 172-91.

ROMER, P. M. (1990) Endogenous Technological Change, Journal of Political Economy 98(5) 71-102.

SAVAGE, D.T., BURKE, M., COUPE, J.D., DUCHESNEAU, T.D., WIHRY, D. F., WILSON, J.A. (1974) The Economics of Environmental Improvement. Houghton Mifflin Company, Boston.

SCRIECIU, S. S. (2007) Can Economic Causes of Tropical Deforestation Be Identified at a Global Level?, Ecological Economics 62(3) 603-12.

STERN, D. I. (2004) The Rise and Fall of the Environmental Kuznets Curve, World Development 32(8) 1419-39.

STERN, D. I., COMMON, M. S., BARBIER, E. B. (1996) Economic Growth and Environmental Degradation: The Environmental Kuznets Curve and Sustainable Development, World Development 24(7) 1151-60.

STUDENMUND, A. H. (2001) Using Econometrics: A Practical Guide, Boston.

THE MINISTRY OF FORESTRY AND WATER AFFAIRS (2015) Türkiye Orman Varlığı 2012, Meteoroloji Genel Müdürlüğü, Ankara.

UNITED NATIONS FRAMEWORK CONVENTION ON CLIMATE CHANGE (2001). Kyoto Protocol to the UN Framework Convention on Climate Change. [http://unfccc.int/resource/docs/cop7/13a01.pdf] Access Date (02.08.2016).

UUSIVUORI, J., LEHTO, E., PALO, M. (2002) Population, Income and Ecological Conditions as Determinants of Forest Area Variation in the Tropics, Global Environmental Change 12(4) 313-23.

WOOLDRIDGE, J. M. (2015) Introductory Econometrics: A Modern Approach, Mason, $\mathrm{OH}$, Thomson/South-Western.

ZHANG, Y., TACHIBANA, S., NAGATA, S. (2006) Impact of SocioEconomic Factors on the Changes in Forest Areas in China, Forest Policy and Economics 9(1) 63-76.

Alındı: 05.01.2017; Son Metin: 18.01.2018 Anahtar Sözcükler: Ekonomik büyüme; eş zamanlı denklemler; ormansızlaşma; iki aşamalı en küçük kareler.

\section{BÖLGESEL GELİR VE ORMANSIZLAŞMA ARASINDAKİ KARŞILIKLI İLIŞKİ: TÜRKİYE ÜZERINNE BİR ÇALIŞMA}

Bu çalışma, büyüme ve çevre arasındaki iki taraflı ilişkiyi ele almaktadır. Çalışmanın amacl, bölgesel ekonomik büyümenin çevresel bozulmaya (ormansızlaşma) nasıl etki ettiğini ve aynı zamanda çevresel kaynakların ekonomik kalkınma için bir arz faktörü olarak işlevini göstermektir. Bu iki yönlü ilişkinin istatistiksel olarak test edilmesi için eşzamanlı denklemler modeli geliştirilmeli ve uygulanmalıdır. Bu ampirik uygulamada, 
ekonomik büyüme bölgesel gelir, çevresel bozulma ise ormansızlaşma ile ölçülmekte ve Türkiye'de 26 İBBS 2 bölgesinin 2004 ve 2014 yılları arasındaki verileri kullanılmaktadır. İki aşamalı en küçük kareler (2SLS) regresyon analizi sonuçları, ormansızlaşma ile bölgesel gelir arasında karşılıklı bir ilişki olduğuna dair güçlü kanıtlar ortaya koyarken, gecikmiş ormansızlaşmanın gelir artışının istatistiksel olarak önemli ve olumlu bir belirleyicisi olduğu gözlemlenmiştir.

\section{THE MUTUAL RELATIONSHIP BETWEEN REGIONAL INCOME AND DEFORESTATION: A STUDY ON TURKEY (1)}

This paper addresses the bilateral relationship between growth and environment. It aims to show how regional economic growth causes environmental deterioration, while the environmental resources function in turn as a supply factor for economic development. A simultaneousequations model is developed and applied to test this two-way relationship statistically, where economic growth is measured by regional income, and environmental deterioration by deforestation. Using data from 26 NUTS 2 regions in Turkey between the years 2004 and 2014, the results of the twostage least squares (2SLS) regression analysis reveal strong evidence on the presence of a mutual relationship between deforestation and regional income, while lagged deforestation is a statistically significant positive determinant of income growth, and vice versa.

ZEYNEP ELBURZ; B.Sc., M.Sc.

Received her B.Sc. in city and regional planning from Dokuz Eylul University, Faculty of Architecture (2006-2010) and her M.Sc. in regional planning from Istanbul Technical University (2010-2012). Currently studies as a Ph.D. student at Dokuz Eylul University. Major interests include, regional economic development, transportation policy.

zeynep.elburz@deu.edu.tr

\section{K. MERT ÇUBUKÇU; BCP, MCRP, PhD}

Received his bachelor's degree in city and regional planning from Middle East Technical University (1993-1997). Earned his MCRP and PhD degrees in city and regional planning from Knowlton School of Architecture at The Ohio State University. His research interests include quantitative planning techniques, spatial statistics, transport modeling, and geographic information systems. mert.cubukcu@deu.edu.tr

PETER NIJKAMP; M.Sc., PhD.

Received his M.Sc. in econometrics and regional economics in 1970, and his Ph.D. in regional economics in 1972, both from the Erasmus University, Rotterdam, the Netherlands. Has honorary doctorates from the Vrije Universiteit Brussel and the National Technical University of Athens. Currently an Emeritus Professor in regional and urban economics, and in economic geography at Vrije Universiteit Amsterdam. p.nijkamp@jads.nl 
